\title{
American Association for the Advancement of Science
}

\author{
St. Louis Meeting, December 30, I935-January 4, I936
}

$\mathrm{S}^{\mathrm{T}}$ T. LOUIS, Missouri, welcomed the American Association for its ninety-seventh meeting at the close of 1935, and the occasion drew together more than three thousand members from its own ranks and from affiliated societies for a series of addresses, meetings and conferences that extended from December 26 until January 4. The local committee, headed by Dr. George T. Moore, director of the famous Missouri Botanical Garden, had made provision for numerous sessions in the new Municipal Auditorium and on the campuses of Washington University, St. Louis University and of their medical schools. The Engineers' Club provided for the meeting of the Section on Engineering, and some societies used hotel meeting rooms-an indication of the number of separate sessions.

So early as 1764, a settlement was located at this point on the great river, and served as a centre of commerce with native tribes in French territory. This frontier post was in the area included in the Louisiana Purchase and it became the city of St. Louis with that transfer of control. By reason of location in a great bend on the bank of the Mississippi between the mouths of the Missouri and Ohio Rivers, it has grown to be the centre of the largest inland waterways in the world, with great industries developed locally and lines of communication radiating in every direction. Splendid bridges built at an early date to establish connexions with the country east of the great river are conspicuous examples of engineering skill. In addition also to fine parks and public buildings, the city has one of the best art galleries in the United States.

Of special scientific interest is first of all the Missouri Botanical Garden, which houses the largest collection of plant life in the western hemisphere. Founded in 1860 and long known as Shaw's Garden, it was originally the home of a wealthy man of British birth who left it with a large endowment for the enjoyment of the public. The Academy of Science of St. Louis was the leader among such organisations in the Central West; it has promoted important scientific work and published a long series of volumes.

St. Louis had previously served as host for three of the noteworthy meetings of the Association. In August 1878, the twenty-seventh meeting was held there during a season "of unprecedented heat". The records of the Association comment on an epidemic of yellow fever then spreading through the south, despite which the city remained healthy, and not a single case of illness was reported among those at the meeting. T. A. Edison was present and told of recent inventions. Even more noteworthy was the second St. Louis meeting, in December 1903. This was shortly before the Louisiana Purchase Exposition which opened in May 1904. Science plaved a prominent part in plans for that event, as the Association had been called upon to aid in building a programme for an International Congress of Arts and Sciences, and the December meeting gave opportunity for discussing and perfecting plans which eventuated in a historic Congress and its published proceedings constituting a valuable record of the progress of science. The third St. Louis meeting in December 1919 established the present organisation and procedure, which were necessitated by the growth of the Association and have enabled it to carry on its present work.

The chief address of the opening session this year was that of the retiring president, Dr. E. L. Thorndike, of Columbia University, who spoke on "Science and Values". He showed that the value to civilisation of human wants and their satisfaction is determinable by scientific methods. When the entire annual budget is interpreted "we pay more to maintain self. respect and the good opinion of others ... than to keep . . . free from the distress of hunger". Man can be influenced to improve his desires and "to find satisfaction in useful work ... and the welfare of others to a degree that the world has never seen" (see also Nature, Jan. 25, p. 144).

The Sigma $\mathrm{Xi}$ address on the second evening, by John Bellamy Taylor, of the General Electric Com. pany, dealt with "The Electric Eye and the Human Eye" and was accompanied by a series of striking demonstrations. The third evening address was the first to be given by Phi Beta Kappa in connexion with the annual meetings of the Association. President W. A. Neilson, of Smith College, the speaker, had chosen as his title "The American Scholar Today", in which he urged on scientific workers the importance of better approach to the laity and the rights of the intelligent public to share the results of the best in scientific research. Dr. Harold G. Moulton, president of the Brookings Institution, gave the address of the fourth evening, on "The Scientific Method in the Investigation of Economic Problems". The speaker maintained that methods of investigation vary necessarily, and scientific treatment is a matter of spirit not limited to investigators in any particular field. Methods used in natural science often lead to over-simplified and imperfect conclusions when applied on economic problems because of fundsmental differences between the two fields which were pointed out.

A series of special afternoon lectures before the Association was opened on December 31 by an address on the pituitary gland and the metabolism of the body. The speaker was Dr. B. A. Houssay, pro. fessor in the medical faculty of Buenos Aires, Argentina, who was the guest of the Association. He presented results of his recent researches on the remarkable influence of a pituitary extract on diabetes. Other addresses in this series were by Prof. E. H. Barbour, of Nebraska, on his extensive studies on "The Proboseidea of the Plains", and by Prof. Frederick Slocum, of Wesleyan University, on "The Changing Picture of the Universe".

The winner of the American Association prize at Pittsburgh in 1934, Dr. V. O. Knudsen, of California, by invitation lectured in this series on the absorption of sound in gases. Dr. H. C. Bryant presented before a large popular audience a series of sound films which had been perfected by several agencies to portray 
geological processes for educational uses. The twelfth annual Gibbs lecture under the joint auspices of the Association and the American Mathematical Society was given by Dean Vannevar Bush, of the Massachusetts Institute of Technology, on "Mechanical Analysis".

The final address in the afternoon series was a lecture and demonstration by Dr. V. K. Zworykin, of the Radio Corporation of America, on "Electron Optical Systems and Their Applications". In its exterior appearing like a telescope, the device is highly sensitive to infra-red rays, which in it are transformed into electrons and then into a visible image. In immediate service in research on life processes, its uses in peace and war are obvious, numerous and of great importance.

Dr. Karl T. Compton, president of the Association, head of the Massachusetts Institute of Technology and chairman of President Roosevelt's Science Advisory Board, in an address on "What's Next in Science", presented the following four aims of science as a programme of response to the needs of the present :

"Scientific search for industrial and other new outlets for farm products, to do away with present temporary need for crop limitations ;

"Scientific improvements in industrial processes, to rid industry of its present self-imposed incubus of tariffs, quotas, and other legislative coddling that handicap efficiency

"Scientific attack on still-unconquered diseases, particularly the debilitating and disabling, rather than the deadly ;

"Finally, research in pure science, as the springboard for forward leaps in the applied sciences."

Within recent years, programmes arranged for meetings of the Association have shown a tendency to multiply joint sessions and symposia as a means for bringing together workers in separate fields and focusing light from diverse sources on problems of common interest. This was conspicuous in the St. Louis programme. Approximately one thousand papers were listed by the sixty sections and societies, but the features that attracted most attention in these special sessions were the joint contributions.

Among the numerous programmes of this type were such as dealt with photo-electricity, land utilisation, botany and human welfare, history of science, genetics and plant breeding, sex hormones, seismology, electric potentials in plants, teaching of chemistry, maturation and learning, and others of similar character. Of marked interest to all was the symposium sponsored by the American Society of Naturalists, which originated the plan and has maintained for many years a programme of invited papers on some topic of active interest to American biological research. The subject this year was "Early Man in America"; the papers discussed climatic changes, recent discoveries of early human cultures and the association of such remains with an extinct fauna. The programme closed after the evening dinner with the presidential address of Dr. John C. Merriam, of the Carnegie Institution of Washington, on the topic "The Extent and Rate of Human Evolution-the Asking of Critical Questions".

The Association Prize for the St. Louis meeting was granted to Dr. P. W. Zimmerman and Dr. A. E. Hitchcock, of the Boyce Thompson Institute, as joint authors of a noteworthy paper on "Responses of Plants to Growth Substances (Phyto-hormones)". This paper, read before the Botanical Society of
America, which met with the Association, presented studies on (1) the specific responses of plants to synthetic growth substances, (2) the movement of such substances in the plant, (3) effects of these substances on root growth, and (4) results when plants are treated with growth substances after exposure to light or darkness.

The Science Exhibition was well housed in the commodious Exhibit Hall of the Municipal Audit. orium, and was an effective presentation of recent scientific progress. Research work, commercial products and apparatus, and new publications were all well represented. The solar heating apparatus of Dr. C. G. Abbot, secretary of the Smithsonian Institution, the electronic eye of Dr. V. K. Zworykin, of the Radio Corporation of America, new seismological apparatus of the Jesuit Seismological Association, scientific aids used by the Federal Bureau of Investigation, U.S. Department of Justice, and the historical exhibit of the St. Louis Academy of Science deserve mention as noteworthy items in a long series among which selection was difficult.

The attention given to sessions at St. Louis by newspapers of the country was conspicuously greater than in previous years. While attributable in good part to greater public interest, this was aided by broader organisation of the Association press service and fuller participation of various public press services and prominent newspapers represented there. For the first time, an Association radio programme was organised by the general secretary of the Association, Dr. O. W. Caldwell, including four national broadcasts and others of more limited range. This must be regarded as a noteworthy extension of the influence of the Association and its meetings.

The addresses of the retiring vice-presidents, given at various times, included the following :

Mathematics, Prof. R. D. Carmichael, of the University of Illinois, on "Linear Differential Equations of Infinite Order";

Physics, Dr. Henry G. Gale, of the University of Chicago, on "The Diffraction Grating" ;

Chemistry, Prof. Joel H. Hildebrand, of the University of California, on "Dipole Attraction and Hydrogen Bond Formation in Their Relation to Solubility" ;

Astronomy, Prof. Frederick Slocum, of Wesleyan University, on "The Changing Picture of the Universe" ;

Geology and Geography, Rev. James B. Macelwane, S.J., of St. Louis University, on "Problems and Progress on the Geologico-Seismological Frontier"; Zoology, Dr. Oscar Riddle, of the Carnegie Institution of Washington, on "The Confusion of Tongues" ;

Botany, Dr. B. O. Dodge, of the New York Botanical Garden, on "Reproduction and Inheritance in Ascomycetes";

Anthropology, Prof. Melville J. Herskovits, of Northwestern University, on "Applied Anthropology and the American Anthropologist";

Psychology, Prof. John E. Anderson, of the University of Minnesota, on "Child Development and the Interpretation of Behavior";

Education, Prof. Guy T. Buswell, of the University of Chicago, on "Some Contributions of the Study of Eye Movements to the Psychology of Perception";

Social and Economic Sciences, Mr. Carl Snyder, of the Federal Reserve Bank, New York City, on "The Role of Capitalism in Civilisation"; 
Historical and Philological Sciences, Dr. Solon J. Buck, director of publications of the National Archives, on "The National Archives and the Advancement of Science" ;

Engineering, Dr. Charles E. Skinner, of the Westinghouse Electric and Manufacturing Company, on "Civilisation's Debt to the Engineer";

Medical Sciences, Dr. Stanhope Bayne-Jones, of Yale University School of Medicine, on "Bacterial Poisons and Their Antidotes";

Agriculture, Dean Jacob G. Lipman, of Rutgers University, on "The Conservation of our Land Resources".

The following officers were elected for the year 1936 : President, Edwin G. Conklin, of Princeton University; Elected Council Members, Austin H. Clark, of the United States National Museum, and Arthur H. Compton, of the University of Chicago; Members of the Executive Committee, Karl T. Compton, of Massachusetts Institute of Technology, and Richard C. Tolman, of California Institute of Technology; Members of the Board of Trustees of Science Service, Burton E. Livingston, of Johns Hopkins University; Member of the Finance Com. mittee, Arthur L. Day, of the Geophysical Laboratory, Carnegie Institution of Washington; Members of the Committee on Grants, Sam F. Trelease, of Columbia University, and Joel Stebbins, of the University of Wisconsin; Secretary of the Section on Agriculture, M. F. Morgan, of Connecticut Agricultural Experiment Station.
Vice-Presidents of the Sections:

G. C. Evans, of the University of California (Mathematics) ;

George B. Pegram, of Columbia University (Physics) ;

Irving Langmuir, of the General Electric Company, Schenectady, N.Y. (Chemistry);

Frederick H. Seares, of Mt. Wilson Observatory (Astronomy) ;

George R. Mansfield, of the United States Geo. logical Survey (Geology and Geography);

Ross G. Harrison, of Yale University (Zoological Sciences) ;

J. M. Greenman, of Missouri Botanical Garden (Botanical Sciences);

Ralph Linton, of the University of Wisconsin (Anthropology) ;

Edward S. Robinson, of Yale University (Psycho. $\log y)$;

Harold G. Moulton of Brookings Institution, Washington, D.C. (Social and Economic Sciences); E. H. Wilkins, of Oberlin College (Historical and Philological Sciences);

W. E. Wickenden, of Case School of Applied Science (Engineering) ;

Joseph T. Wearn, of Western Reserve University (Medical Sciences);

P. E. Brown, of Iowa State College (Agriculture);

E. S. Evenden, of Columbia University (Education).

Henry B. Ward.

\section{New Spectrographic Apparatus}

$\mathrm{M}^{\mathrm{r}}$ ESSRS. ADAM HILGER, Ltd., have forwarded to us some interesting leaflets on recent developments in spectrographic apparatus. The alignment or collimation of the light source with the axis of the collimator is of great importance when any quantitative measurements of a photometric char-

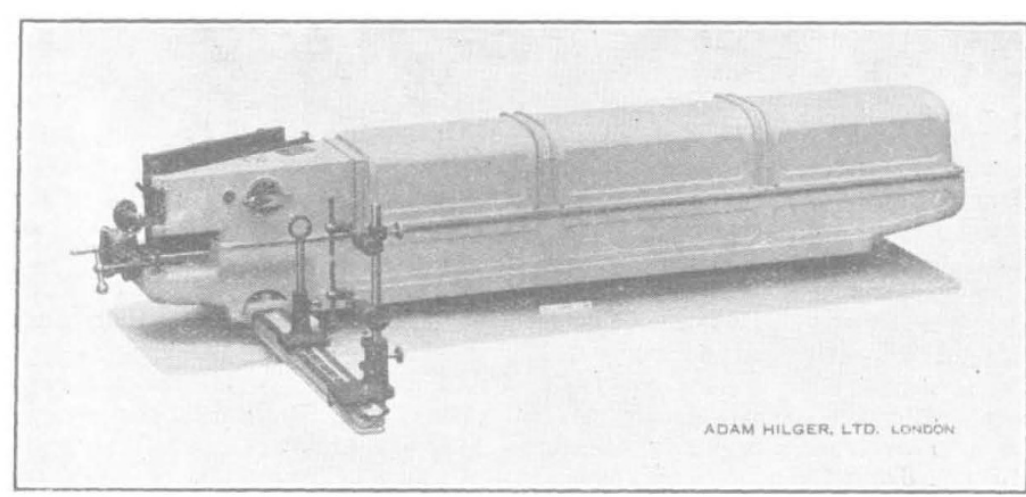

FIG. 1.

acter have to be made. Several of the spectrographs are now constructed with an accessory bar the axis of which is strictly parallel to that of the collimator. Photometer lenses and even light sources can be mounted on this 'optical bench', and the dangers of imperfect collimation are much reduced. When these instruments are used in routine testing, the time saved can be very considerable.

An entirely new departure in spectrographic apparatus is the construction of a fully automatic adjustment spectrograph. By simply rotating a handle, a glass optical train replaces one of quarte. In addition, any desired specteal range can be obtained on the plate, the focus and plate tilt being automatically set. It thus be. comes quite practical to photo. graph on the same plate an ultra-violet region with the quarte. train together with a region in the near infra-red with the glass optical parts. The enormous saving of time thus effected will be well appreciated by the many users of the prototype instrument, the Hilger E.l. It is now actually much easier to take a spectrogram with this instrument than to take an ordinary photograph with a box camera.

Concurrently with this simplification of the mechanical operations in taking a spectrum plate, there has been a steady improvement in the standard of definition of the prismsand lenses. This is strikingly shown in the enlargements of the iron triplet at $3100 \mathrm{~A}$. taken with the modern equivalents of the $E .2, E .1$, and a 3-metre quarte 